\title{
Erratum to: Genetic Diversity of a Global Population of Colletotrichum Coccodes Using Amplified Fragment Length Polymorphism Markers
}

Kholoud M. Alananbeh • Leah Tsror Lahkim •

Neil C. Gudmestad

Published online: 1 November 2013

(C) Potato Association of America 2013

Erratum to: Am. J. Potato Res.

DOI 10.1007/s12230-013-9331-2

The correct spelling of the second author's first name is Leah.

The online version of the original article can be found at http://dx.doi.org/ 10.1007/s12230-013-9331-2.

K. M. Alananbeh • N. C. Gudmestad $(\bowtie)$

Department of Plant Pathology, North Dakota State University,

Walster Hall 310, Fargo, ND 58102, USA

e-mail: neil.gudmestad@ndsu.edu

K. M. Alananbeh

e-mail: kholoudennab@gmail.com

L. T. Lahkim

Plant Pathology Unit, Gilat Research Center, Mobile Post,

Negev 85280, Israel

Present Address:

K. M. Alananbeh

Taibah University, Medinah 30002, Saudi Arabia 